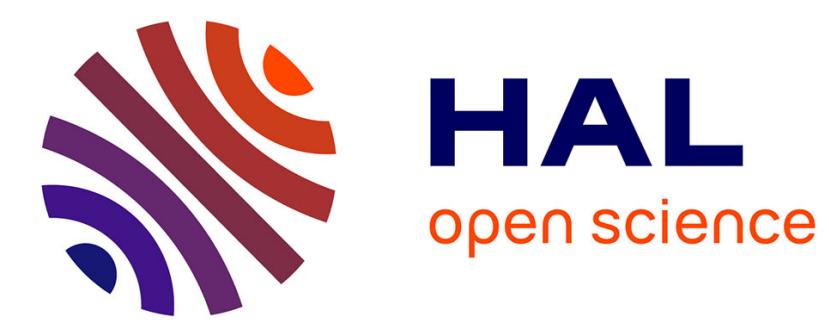

\title{
Nature of defects in heavily Te-doped GaAs
}

\author{
D.L. Williamson, M. Kowalchik, A. Rocher, P. Gibart
}

\section{To cite this version:}

D.L. Williamson, M. Kowalchik, A. Rocher, P. Gibart. Nature of defects in heavily Te-doped GaAs. Revue de Physique Appliquée, 1983, 18 (8), pp.475-478. 10.1051/rphysap:01983001808047500 . jpa00245108

\section{HAL Id: jpa-00245108 https://hal.science/jpa-00245108}

Submitted on 1 Jan 1983

HAL is a multi-disciplinary open access archive for the deposit and dissemination of scientific research documents, whether they are published or not. The documents may come from teaching and research institutions in France or abroad, or from public or private research centers.
L'archive ouverte pluridisciplinaire HAL, est destinée au dépôt et à la diffusion de documents scientifiques de niveau recherche, publiés ou non, émanant des établissements d'enseignement et de recherche français ou étrangers, des laboratoires publics ou privés. 
Classification

Physics Abstracts

$76.80 \mathrm{Y}-61.70 \mathrm{Jc}$

\title{
Nature of defects in heavily Te-doped GaAs
}

\author{
D. L. Williamson (*), M. Kowalchik \\ SERI, 1617 Cole blvd., Golden, Colorado 80401, USA
}

\author{
A. Rocher \\ Laboratoire d'Optique Electronique du CNRS, 29, rue Jeanne Marvig, 31400 Toulouse, France \\ and P. Gibart
}

Laboratoire Physique du Solide et Energie Solaire, CNRS, Sophia Antipolis, 06560 Valbonne, France

(Reçu le 7 décembre 1982, révisé le 5 avril 1983, accepté le 12 avril 1983)

\begin{abstract}
Résumé. - GaAs fortement dopé en tellure a été étudié par spectroscopie Mössbauer sur ${ }^{125} \mathrm{Te}$ et par microscopie électronique en transmission (TEM). Pour $N_{\mathrm{D}}-N_{\mathrm{A}}>10^{19} \mathrm{~cm}^{-3}$, des microprécipités apparaissent le long des boucles de dislocations sur les microphotographies, tandis qu'un second site Te présentant un couplage quadrupolaire apparaît dans les spectres Mössbauer. Ces deux faits peuvent s'expliquer par l'existence de microprécipités de tellurure de gallium, probablement $\mathrm{Ga}_{2} \mathrm{Te}_{3}$.
\end{abstract}

Abstract. - Heavily Te-doped GaAs has been studied by ${ }^{125}$ Te Mössbauer spectroscopy and transmission electron microscopy (TEM). It is shown that for $N_{\mathrm{D}}-N_{\mathrm{A}}>10^{19} \mathrm{~cm}^{-3}$, microprecipitates are observed along dislocations loops on TEM micrographs whereas a quadrupole split second site appears in Mössbauer spectra. Both features are consistent with the existence of microprecipitates of gallium telluride, probably $\mathrm{Ga}_{2} \mathrm{Te}_{3}$.

\section{Introduction.}

Tellurium is commonly used as an n-type dopant of GaAs. In review papers, Hurle $[1,2]$ discussed a model of point defect equilibria in $\mathrm{GaAs}$ and the effect of heat treatment on Te-doped GaAs. Further predictions regarding the nature of defects in this material were recently made by Fewster [3]. In a previous study, Williamson and Gibart [4] used ${ }^{125} \mathrm{Te}$ Mössbauer spectroscopy and electrical measurements to identify at least two types of $\mathrm{Te}$ sites through differences in local symmetry for different doping densities.

There is new interest in GaAs tunnel diodes for the interconnection of two diodes in a multi-junction solar cell $[5,6]$. The $n$ and $p$-type dopants in such a tunnel diode should allow high doping densities $\left(\simeq 10^{19} \mathrm{~cm}^{-3}\right)$, and the diffusion coefficients of both dopants should be as low as possible to avoid interdiffusion during the growth of the high band-gap

(*) Permanent address : Physics Department, Colorado School of Mines, Golden, Colorado 80401, USA. top solar cell. To date, $\mathrm{Te}$ is the best $\mathrm{n}$-type candidate although there are problems of high doping densities because of high degrees of compensation and the formation of microprecipitates. Heat treatments drastically alter the carrier densities.

In order to improve the design of GaAs tunnel diodes for ohmic solar cell interconnections, more information is needed on the nature and formation of defects in heavily doped GaAs. This study combines ${ }^{125} \mathrm{Te}$ Mössbauer spectroscopy and electron microscopy to examine heavily Te-doped GaAs both in the as-grown state and after various heat treatments.

\section{Experimental.}

2.1 SAMPLE PREPARATION. - Thick layers $(\simeq 300 \mu \mathrm{m})$ of GaAs single crystal were grown by liquid phase epitaxy (LPE) using the sliding boat technique. Tellurium enriched to $96 \%{ }^{125} \mathrm{Te}$ was used in the $\mathrm{Ga}$ melt. The substrate $(\simeq 300 \mu \mathrm{m})$ was removed by lapping to enable the transmission Mössbauer measu- 
Table I. - Electrical and Mössbauer parameters before and after annealing of heavily Te-doped GaAs crystals. $N_{\mathrm{D}}-N_{\mathrm{A}}$ is the free carrier concentration and $\mu$ is the mobility, both obtained from room temperature Van der Pauw measurements. $\Gamma$ is the full width at half maximum based on single-line Lorentzian fits to the $77 \mathrm{~K}$ Mössbauer data and $N_{\mathrm{Te}}$ is the total Te concentration obtained from the Mössbauer measurements. Uncertainties are given in parentheses.

\begin{tabular}{|c|c|c|c|c|}
\hline Sample $\left(^{a}\right)$ & $\begin{array}{c}N_{\mathrm{D}}-N_{\mathrm{A}} \\
\left(10^{19} \mathrm{~cm}^{-3}\right)\end{array}$ & $\begin{array}{c}\mu \\
\left(\mathrm{cm}^{2} / \mathrm{V}-\mathrm{s}\right)\end{array}$ & $\begin{array}{c}\Gamma \\
(\mathrm{mm} / \mathrm{s})\end{array}$ & $\begin{array}{c}N_{\mathrm{Te}} \\
\left(10^{19} \mathrm{~cm}^{-3}\right)\end{array}$ \\
\hline 2 (as-grown) & 1.25 & 1280 & $6.79(11)$ & $2.8(7)$ \\
2A (annealed) $\left(^{b}\right)$ & 0.5 & 800 & $6.45(24)$ & $2.8(7)$ \\
3 (as-grown) & 0.95 & 1660 & $6.39(19)$ & $2.0(5)$ \\
3A (annealed) (c) & 0.9 & 820 & $7.36(38)$ & $2.0(5)$ \\
3B (annealed) (d) & 0.5 & 1200 & $5.98(24)$ & $2.0(5)$ \\
\hline
\end{tabular}

$\left({ }^{a}\right)$ Same sample designation as used in reference 4.

(b) Sample 2 annealed at $1173 \mathrm{~K}$ under $1 \mathrm{~atm}$. $\mathrm{As}_{2}$ for $72 \mathrm{~h}$ and quenched into water.

(c) Sample 3 annealed at $893 \mathrm{~K}$ under $1 \mathrm{~atm}$. As $\mathrm{s}_{2}$ for $80 \mathrm{~h}$ and quenched into water.

${ }^{(d)}$ Sample 3A annealed at $1373 \mathrm{~K}$ under $1 \mathrm{~atm}$. $\mathrm{As}_{2}$ for $48 \mathrm{~h}$ and quenched into water.

rements. The same samples used for Mössbauer spectroscopy were subsequently thinned to $100 \mathrm{~nm}$ by mechanochemical polishing for the TEM observations.

During heat treatments, samples were put in a sealed quartz ampoule with arsenic in excess at the equilibrium temperature. (LPE GaAs is grown under very low arsenic pressure and annealing under $\mathrm{As}_{2}$ pressure creates $\mathrm{Ga}$ vacancies with $\mathrm{V}_{\mathrm{Ga}} \propto P_{\mathrm{As}_{2}}^{1 / 2}$.) After heat treatment, the ampoules were quenched to room temperature in water. Details on the different heat treatments together with electrical and Mössbauer data are given in table $\mathrm{I}$.

2.2 Mössbauer Measurements. - Detailed description of the Mössbauer measurements and analysis were presented in reference 4 . For samples having carrier densities up to $10^{19} \mathrm{~cm}^{-3}$, the Mössbauer spectra can be fitted with a single Lorentzian line having a line width which is equal to the natural value $\left(2 \Gamma_{0}=5.20 \mathrm{~mm} / \mathrm{s}\right)$ within an error of $\pm 6 \%$. These results were interpreted as $\mathrm{Te}$ in substitutional $\mathrm{Te}_{\mathrm{As}}^{+}$ sites with cubic symmetry. The observed isomer shift, $\delta=-0.1 \pm 0.1 \mathrm{~mm} / \mathrm{s}$ relative to the $\mathrm{Cu}(\mathrm{Sb})$ source, indicates an electronic structure for the $\mathrm{Te}$ atoms similar to $\mathrm{ZnTe}$, i.e. $\mathrm{Te}^{-2}$ ionic state for $\mathrm{Te}_{\mathrm{As}}$ donors in GaAs.

The samples of particular interest here were grown with $5 \times 10^{-3}$ (\# 2) and $10^{-2}$ (\# 3) Te (atomic conc.) in the melt in order to attempt to achieve heavier donor concentrations. Figure 1 shows Mössbauer spectra of samplès \# 3 , \# 3A, and \# 3B. Single line fits to the spectra yield linewidths (Table I) which are much broader than the natural width. Samples 2 and 2A also yield broadened linewidths and it was shown in reference 4 that the broadening exhibited by sample 2 could be accounted for by a superposition of a single line with $\mathrm{Te}_{\mathrm{As}}^{+}$parameters

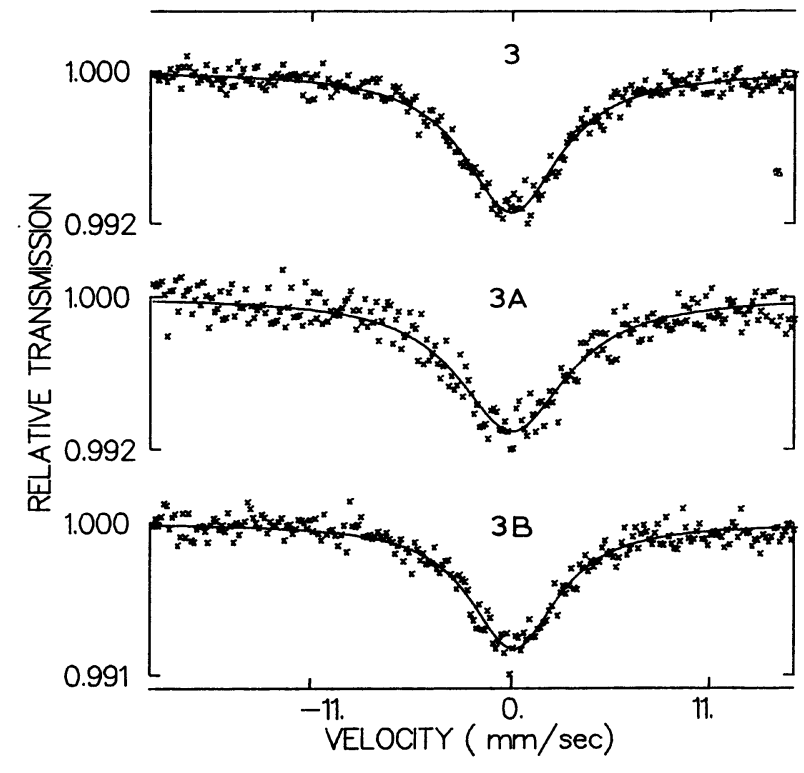

Fig. 1. - Mössbauer spectra from samples 3, 3A and 3B. Solid lines are least-square computer fits of single Lorentzian lines with linewidths $\Gamma$ given in table $I$. Source and absorber at $77 \mathrm{~K}$.

and a quadrupole pair with quadrupole splitting $\Delta=3.7 \pm 0.3 \mathrm{~mm} / \mathrm{s}$, and isomer shift $\delta=0.3 \pm$ $0.1 \mathrm{~mm} / \mathrm{s}$ at $77 \mathrm{~K}$.

To determine whether the broadening could be clearly attributed to either $\mathrm{GaTe}$ or $\mathrm{Ga}_{2} \mathrm{Te}_{3}$ precipitates, we obtained Mössbauer spectra from bulk $\mathrm{GaTe}$ and $\mathrm{Ga}_{2} \mathrm{Te}_{3}$ as presented in figure 2. Both absorbers were prepared by grinding the materials to less than $150 \mu \mathrm{m}$ particle size and pressing into $2.5 \mathrm{~cm}$ disks using powdered sugar as an inert binder. The material was also examined by $\mathrm{X}$-ray diffraction and found to be single phase for both $\mathrm{GaTe}$ and $\mathrm{Ga}_{2} \mathrm{Te}_{3}$ 


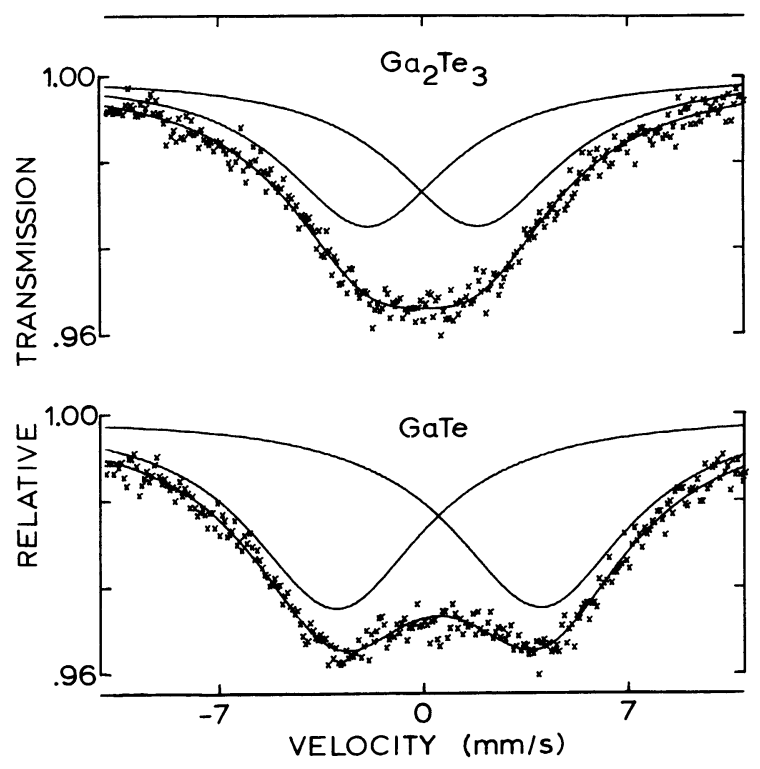

Fig. 2. - Mössbauer spectra of bulk $\mathrm{Ga}_{2} \mathrm{Te}_{3}$ and GaTe. Solid lines passing through the data points are computer fits of the superposition of Lorentzian lines indicated. Parameters from the fits are given in table II. Source and absorber at $77 \mathrm{~K}$. Note that the velocity scale here is expanded compared to figure 1 .

compositions. Both Mössbauer spectra were adequately fitted by a quadrupole pair as indicated in figure 2 . The spectral parameters from these fits are listed in table II together with values reported by others [7]. The differences in the values of $\Delta$ found here and those of Dragunas and Makaryunas [7] may be due to differences in experimental linewidths (no values of $\Gamma$ were given in Ref. 7), particularly for $\mathrm{Ga}_{2} \mathrm{Te}_{3}$ which has an unresolved quadrupole splitting (Fig. 2). Note, however, that the smaller value of $\Delta$ found here for $\mathrm{Ga}_{2} \mathrm{Te}_{3}$ is in much better agreement with the value of $\Delta$ given above for the two site model fit to sample 2 [4].

The linewidths $(\Gamma)$ observed here for $\mathrm{Ga}_{2} \mathrm{Te}_{3}$ and GaTe are both significantly broader than the natural width (after accounting for absorber thickness broadening), but this can be attributed to the following structural features of these two compounds: $\mathrm{Ga}_{2} \mathrm{Te}_{3}$ is a deficit cubic structure ( $\bar{F} \overline{4} 3 \mathrm{~m}$ space group) in

Table II. - Mössbauer parameters of $\mathrm{Ga}_{2} \mathrm{Te}_{3}$ and $\mathrm{GaTe}$ at $77 \mathrm{~K}$. $\delta$ is the isomer shift relative to the $\mathrm{Cu}(\mathrm{Sb})$ source (also at $77 \mathrm{~K}$ ). $\Gamma$ is the full width at half maximum resonance. $\Delta$ is the quadrupole splitting. Uncertainties are given in parentheses.

\begin{tabular}{|l|c|c|c|l|}
\hline & $\delta(\mathrm{mm} / \mathrm{s})$ & $\Gamma(\mathrm{mm} / \mathrm{s})$ & $\Delta(\mathrm{mm} / \mathrm{s})$ & \multicolumn{1}{|c|}{ Ref. } \\
\hline $\mathrm{Ga}_{2} \mathrm{Te}_{3}$ & $0.1(1)$ & $6.3(2)$ & $3.6(1)$ & This work \\
& $0.2(2)$ & - & $4.5(2)$ & Ref. 7 \\
$\mathrm{GaTe}$ & $0.5(1)$ & $7.0(2)$ & $6.9(1)$ & This work \\
& $0.3(2)$ & - & $6.5(2)$ & Ref. 7 \\
\hline
\end{tabular}

that only two-thirds of the metallic lattice positions are occupied by $\mathrm{Ga}$. This causes the removal of cubic point symmetry $\left(T_{d}\right)$ of the Te sites and the appearance of the quadrupole interaction at $\mathrm{Te}$ sites (so that $\Delta \neq 0$ ). Since the vacant sites are not ordered (to our knowledge) the point symmetry of the Te sites will not all be the same so that a distribution of quadrupole splittings will occur and be evident as a broadened value of $\Gamma$ in our fitting procedure. GaTe is monoclinic (B2/m space group) and has recently been shown [8] to have three different Te sites per unit cell. Each site has only $2 / m\left(C_{2 h}\right)$ point symmetry. The slightly different $\mathrm{Te}-\mathrm{Ga}$ bond distances and bond angles [8] for these three $\mathrm{Te}$ sites probably generate three slightly different values of $\Delta$ (with average $\Delta$ given in table II) thereby causing the broadened value of $\Gamma$ in our simple two line fit.

To account for the line broadening in the GaAs : Te samples, the $77 \mathrm{~K}$ spectra from the 5 samples $(2,2 \mathrm{~A}$, 3, 3A, 3B) were all fitted with a single line fixed at the donor (and acceptor) value of $-0.1 \mathrm{~mm} / \mathrm{s}$, fixed linewidth at $5.25 \mathrm{~mm} / \mathrm{s}$ (natural width + instrumental broadening [4]) and the second site parameters fixed at either the $\mathrm{Ga}_{2} \mathrm{Te}_{3}$ or $\mathrm{GaTe}$ values listed in table II. The only adjustable fit parameters were, therefore, the intensities of the two components. In all 5 cases, the $\mathrm{Ga}_{2} \mathrm{Te}_{3}$ parameters gave a slightly better fit as indicated by the $\chi^{2}$ indicator. The ratios of the integrated intensity (area) of the quadrupole lines compared to the total resonance area from the $\mathrm{Ga}_{2} \mathrm{Te}_{3}$ fits are listed in table III.

Table III. - Fractional Mössbauer resonance due to quadrupole split second site with $\mathrm{Ga}_{2} \mathrm{Te}_{3}$ fit parameters.

\begin{tabular}{|l|r|r|r|r|c|}
\hline Sample & 2 & $2 \mathrm{~A}$ & 3 & $3 \mathrm{~A}$ & $3 \mathrm{~B}$ \\
\hline Fraction & 0.56 & 0.48 & 0.46 & 0.66 & 0.30 \\
\hline
\end{tabular}

2.3 TeM OBSERVATIONS. - TEM analysis was made with an EM400 Philips microscope. Figure 3 shows a TEM micrograph from sample $2 \mathrm{~A}$ (annealed $72 \mathrm{~h}$ at $900^{\circ} \mathrm{C}$ ). The dislocation loops are about $0.2 \mu \mathrm{m}$ in diameter and have a density of about $3 \times 10^{-7} \mathrm{~cm}^{-2}$. Small microprecipitates $(\simeq 10 \mathrm{~nm}$ dia.) can be seen along the dislocation loops. Similar features for

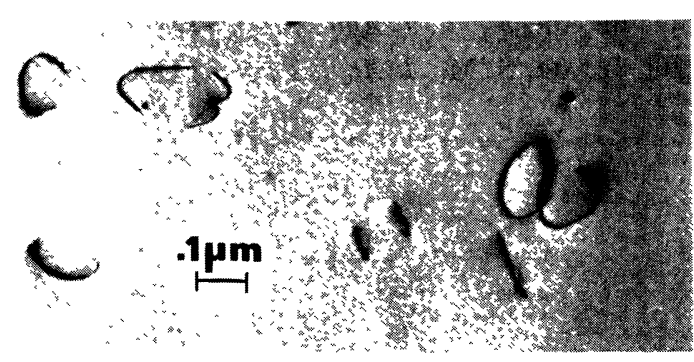

Fig. 3. - TEM micrograph of sample 2A. 
annealed Te-doped GaAs have been reported by others [9]. The nature of the precipitates was not characterized by TEM since their size is too small to give any structural information.

For sample $3 \mathrm{~B}$ (annealed $48 \mathrm{~h}$ at $1100^{\circ} \mathrm{C}$ ), the TEM analysis reveals neither dislocation loops nor microprecipitates.

\section{Discussion.}

The number of free carriers $\left(N_{\mathrm{D}}-N_{\mathrm{A}}\right)$ in the as-grown samples 2 and 3 is only about half of the total Te concentration (Table I) and the Mọ̈ssbauer analysis in table III suggests that about half of the Te atoms are in a second site with parameters similar to $\mathrm{Ga}_{2} \mathrm{Te}_{3}$. Since such $\mathrm{Te}$ atoms would be electrically inactive, the Mössbauer and Hall data for these two samples are consistent.

Sample 2A, annealed at $900^{\circ} \mathrm{C}$ for $72 \mathrm{~h}$, shows a large reduction in $N_{\mathrm{p}}-N_{\mathrm{A}}$ and mobility, whereas the Mössbauer analysis shows a relatively small reduction in the linewidth. The TEM micrograph (Fig. 3) clearly shows the presence of dislocation loops, each decorated with a precipitate in this sample. These data are consistent with the formation of Te-associated acceptors and only a slight dissolution of the precipitates during the anneal. As discussed previously [4], the Mössbauer resonance of the acceptor site is indistinguishable from the donor site and, therefore, must be of higher symmetry than the $\mathrm{Te}_{\mathrm{As}} \mathrm{V}_{\mathrm{Ga}}$ acceptor complex proposed by others $[2,10]$. Thus, the reduced Mössbauer linewidth for $2 \mathrm{~A}$ compared to 2 is attributed to a reduction in the fraction of Te atoms in the $\mathrm{Ga}_{2} \mathrm{Te}_{3}$ precipitated phase by the amount shown in table III. The reduction in mobility is attributed to the increased fraction of acceptors (formed pri- marily at the expense of the donors which existed before the anneal).

Sample $3 \mathrm{~A}$ was obtained by annealing at a relatively low temperature of $620^{\circ} \mathrm{C}$. (The growth temperature was from $800^{\circ} \mathrm{C}$ to $700^{\circ} \mathrm{C}$.) The increase in Mössbauer linewidth suggests an increase in $\mathrm{Te}$ as $\mathrm{Ga}_{2} \mathrm{Te}_{3}$ precipitates from a $46 \%$ fraction to $66 \%$ yet $N_{\mathrm{D}}-N_{\mathrm{A}}$ decreased by only about $5 \%$. These data do not appear consistent so the increased linewidth might be due to the formation of GaTe which would produce the same linewidth change as $\mathrm{Ga}_{2} \mathrm{Te}_{3}$ for a smaller amount of $\mathrm{Te}$ as $\mathrm{GaTe}$ because of its larger quadrupole splitting (Table II). No TEM data were obtained from this sample.

Subsequent annealing of sample $3 \mathrm{~A}$ at $1100{ }^{\circ} \mathrm{C}$ (to produce 3B) greatly reduced the Mössbauer linewidth and $N_{\mathrm{D}}-N_{\mathrm{A}}$ while raising the mobility to a value intermediate to those of 3 and $3 \mathrm{~A}$. Similar to the affects of the $2 \mathrm{~A}$ anneal, this behaviour is attributed to dissolution of the precipitates and the concurrent formation of acceptors. Although the annealing temperature was higher than the melting point of $\mathrm{Ga}_{2} \mathrm{Te}_{3}$ (and $\mathrm{GaTe}$ ) this phase may form again upon cooling. The Mössbauer data in table II suggest that about $30 \%$ of the Te remains precipitated. The dislocation loop density and precipitate size was apparently reduced to sufficiently small values to prevent their observation by TEM. Other studies [9] have shown that the dislocation loops in Te-doped $\mathrm{GaAs}$ dissolve for annealing temperatures above $900{ }^{\circ} \mathrm{C}$.

No evidence was obtained from this work for the split interstitial defect $T e_{i} V_{G_{2}} G_{i}$ recently proposed by Fewster [3]; however, the annealing conditions used here (excess As) are not conducive to the formation of such defects. Our observations described above are in good agreement with several other aspects of the defect model described by Fewster [3].

References

[1] Hurle, D. T. J., J. Phys. Chem. Solids 40 (1979) 613-25.

[2] Hurle, D. T. J., J. Phys. Chem. Solids 40 (1979) 627-37.

[3] Fewster, P. F., J. Phys. Chem. Solids 42 (1981) 883-89.

[4] Williamson, D. L. and Gibart, P., J. Phys. C 14 (1981) 2517-26.

[5] Bedair, S. M., J. Appl. Phys. 50 (1979) 7267-8.

[6] Bedair, S. M., J. Appl. Phys. 51 (1980) 3935-7.
[7] Dragunas, A. K. and Makaryunas, K. V., Proc. 5th Int. Conf. Mössbauer Spectroscopy Vol. 3, Ed. M. Hucl and T. Zemckik (Praque : Czechoslovak Atomic Energy Commission) 1975, p. 517-21.

[8] Julien-Pouzol, M., Jaulmes, S., Guittard, M. and Alapini, F., Acta Cryst. B35 (1979) 2848.

[9] Laister, D. and Jenkins, G. M., Philos. Mag. 16 (1971) 1077

[10] Williams, E. W., Phys. Rev. 168 (1968) 922-8. 